\title{
Pengembangan LKS Sains dengan Setting Model Pembelajaran PBL untuk Meningkatkan Keterampilan Berpikir Kritis dan Efikasi Diri
}

\author{
I Gusti Lanang Agung Adi Prana ${ }^{1}$, I Wayan Sadia ${ }^{2}$, Ida Bagus Jelantik Swasta \\ Universitas Pendidikan Ganesha \\ e-mail: \{ adi.prana, i.wayan.sadia, jelantik.swasta\}@pasca.undiksha.ac.id\}
}

\begin{abstract}
Abstrak
Penelitian ini bertujuan untuk menghasilkan LKS sains yang memenuhi syarat validitas, kepraktisan dan efektivitas dengan setting model pembelajaran PBL untuk meningkatkan keterampilan berpikir kritis dan keyakinan diri siswa SMP. Pengembangan LKS ini mengacu pada model pengembangan 4-D yang disarankan oleh Thiagarajan et al. (1974) yaitu define, design, develop dan disseminate. Validasi instrumen dan produk dilakukan oleh dua orang tenaga ahli dan sebelas orang praktisi. Kepraktisan dinilai oleh guru dan siswa, dan data keefektifan didapatkan dari 38 orang siswa. Metode analisis data dilakukan dengan analisis deskriptif kuantitatif terhadap validitas dan kepraktisan LKS. Efektivitas LKS dilakukan dengan one group pretest posttest design. Efektivitas LKS dianalisis dengan uji t pihak kanan. Hasil penelitian menunjukan (1) LKS dinyatakan valid dengan skor rata-rata validitas 3,40, (2) LKS dinyatakan praktis dengan skor rata-rata kepraktisan 3,30, (3) LKS dinyatakan efektif untuk meningkatkan keterampilan berpikir kritis dengan thitung >ttabel $(13,407>1,684)$ dan (4) LKS dinyatakan efektif untuk meningkatkan efikasi diri siswa dengan thitung > ttabel (16,838 > 1,687). Berdasarkan hasil penelitian dapat disimpulkan bahwa LKS sains telah memenuhi syarat validitas, kepraktisan, dan efektivitas dengan setting model pembelajaran PBL untuk meningkatkan keterampilan berpikir kritis dan efikasi diri siswa SMP.
\end{abstract}

Kata Kunci: Lembar Kerja Siswa, Problem Based Learning, Keterampilan berpikir kritis, Efikasi diri

\begin{abstract}
The purpose of this research was to produce a science student worksheet (LKS) that fulfills validity, practicality, and effectiveness requirements based on problem based learning model setting to improve junior high school students' critical thinking skill and self-efficacy. The development of this student worksheet (LKS) was based on 4D development model suggested by Thiagarajan et al. (1974) they are define, design, develop and disseminate. The tests in this student worksheet were validated by two experts and eleven practitioners. The practicality was scored by the three teachers and the students, and the effectiveness data was acquired from 38 students. The data analysis method was done by using descriptive quantitative analysis toward the validity and the effectiveness of the student worksheet (LKS). The student worksheet effectiveness was done by using one group pretest posttest design. The student worksheet effectiveness was analyzed by using right side t-test. The result of the research shows that (1) the student worksheet (LKS) is valid with average score of the validity is 3.40 , (2) the student worksheet (LKS) is practical with average score of the practicality is 3.30 , (3) the student worksheet (LKS) is effective to improve students' critical thinking skill with tcount $>$ ttabel $(13,407>1,684)$ and (4) the student worksheet $(L K S)$ is effective to improve students' selfefficacy with tcount $>$ ttabel $(16,838>1,687)$. Based on the result of this research, it can be concluded that science student worksheet (LKS) has fulfilled validity, practicality, and effectiveness based on problem based learning model setting requirements to improve students' critical thinking skill and students' self-efficacy.
\end{abstract}

Keywords: Student Worksheet, Problem Based Learning, Critical Thinking Skills, Self-efficacy 


\section{Pendahuluan}

Perkembangan ilmu pengetahuan dan teknologi telah membawa perubahan yang mendasar terhadap pola pikir manusia tentang alam dan sekitarnya. Berbagai kemajuan di bidang IPTEK yang bersifat makro maupun mikro berimplikasi pada munculnya kekuatan suatu bangsa yang handal, di mana indikator majunya suatu bangsa dapat diketahui dari tingkat kemampuan sumber daya manusia yang dimilikinya. Tidak dapat dipungkiri bahwa mutu dan kualitas sumber daya manusia berakar pada pendidikan sebagai wahana belajar dalam kerangka pendidikan nasional. Sistem pendidikan yang baik akan memberikan suatu perubahan terhadap pola pikir dan prilaku Bangsa. Berbagai upaya dilakukan untuk mengukur tingkat kemampuan kognitif siswa dalam berbagai bidang secara Internasional salah satunya melalui lembaga PISA.

Hasil studi lembaga international Programme for International Student Assesment (PISA) yang merilis hasil penelitiannya pada tahun 2015, menunjukan kompetensi sains, dari 382 poin pada tahun 2012 menjadi 403 poin sehingga Indonesia menduduki peringkat 62 dari 70 Negara. Hasil PISA ditahun 2015 masih perlu ditingkatkan mengingat Indonesia masih berada diurutan rendah jika dibandingkan dengan Negara-negara ASEAN, sehingga hal ini menjadi tantangan untuk tetap optimis dalam berbagai upaya perbaikan mutu pendidikan.

Fakta rendahnya kualitas pendidikan menuntut pemerintah untuk melakukan pembaharuan dalam sistem pendidikan. Salah satunya yaitu dikeluarkannya kurikulum 2013 sebagai dasar dalam pelaksanaan proses pendidikan Indonesia. Keterlaksanaan kurikulum 2013 adalah pembelajaran kompetensi dengan memperkuat proses pembelajaran dan penilaian autentik untuk mencapai kompetensi sikap, pengetahuan dan keterampilan. Penguatan proses pembelajaran dilakukan melalui pendekatan scientific. IPA memiliki dimensi sikap ilmiah (scientific attitude), proses ilmiah (scientific process), dan produk ilmiah (scientific product) berupa pengetahuan (Kemendiknas, 2011:1). Oleh karena itu keberhasilan keterlaksaan kurikulum 2013 tidak hanya dipengaruhi oleh proses pembelajaran yang menuntut guru untuk selalu kreatif dalam mengembangkan metode yang digunakan tetapi tersedianya perangkat pengajaran juga penting dalam menunjang proses pembelajaran IPA.Namun, pada kenyataanya dengan turunya perangkat mengajar dari pusat membuat kreativitas guru dalam mengembangkan perangkat yang mampu menyesuaikan dengan karakteristik peserta didik disekolah menjadi terbatas.

Salah satu perangkat mengajar yang bisa dikembangkan oleh guru yaitu Lembar Kerja Siswa (LKS ). Menurut Hendro Darmodjo dan Jenny R. E. Kaligis (1992 : 40), Lembar Kerja Siswa (LKS) merupakan sarana pembelajaran yang dapat digunakan guru dalam meningkatkan keterlibatan atau aktivitas siswa dalam proses belajar-mengajar.Pada umumnya, LKS berisi petunjuk praktikum, percobaan yang bisa dilakukan di rumah, materi untuk diskusi, teka teki silang, tugas portofolio, dan soal-soal latihan,maupun segala bentuk petunjuk yang mampu mengajak siswa beraktivitas dalam proses pembelajaran. Pada kenyataannya, meskipun di lapangan banyak ditemukan berbagai bentuk LKS, namun guru kurang mengetahui bagaimana kriteria LKS yang baik yang dapat digunakan dalam membantu mencapai tujuan pembelajaran.

Berdasarkan hasil observasi dan wawancara dengan beberapa orang guru di SMP Negeri 4 Singaraja, terdapat beberapa temuan bahwa pengunaan LKS di kelas VII khususnya pada mata pelajaran IPA, terdapat beberapa kelemahan dimana guru masih bingung dalam mengembangkan Lembar Kerja Siswa (LKS) yang mampu mengakomodasi kebutuhan siswa. LKS yang digunakan guru belum diketahui kriteria validitas dan kepraktisan dalam pengembangannnya. LKS cetakan yang diterbitkan dari beberapa sumber bagian besar bersifat hafalan, terlalu banyak soal-soal dan masalah yang ada kurang melatih daya kemampuan berpikir kritis (Critical thinking) siswa. Disamping itu LKS yang ada terkesan kurang menarik serta belum menunjukan aktivitas pembelajaran yang bersifat student centered. Beberapa kelemahan yang ada berdampak pada lemahnya tingkat keyakinan (self-efficacy) siswa dalam menghadapi berbagai permasalahan yang ada.

Menurut Bandura (1997) menyatakan, self - efficacy sebagai keyakinan seseorang terhadap kemampuannya untuk mengatur dan melaksanakan tindakan-tindakan dalam mencapai tujuan yang ditetapkan, dan berusaha untuk menilai tingkatan dan kekuatan di seluruh kegiatan. Namun, pada kenyataannya self-efficacy siswa di SMP Negeri 4 Singaraja khususnya pada kelas VII masih rendah dilihat dari sikap keraguan siswa dalam mengambil keputusan dan siswa cenderung menunjukan sikap yang cemas serta gelisah saat mengikuti ulangan. 
Rendahnya self-efficacy siswa akan berdampak terhadap prestasi belajar terutama dalam menghadapi soal yang memerlukan keterampilan berpikir kritis. Berpikir kritis adalah proses terorganisasi yang melibatkan aktivitas mental seperti dalam pemecahan masalah (problem solving), pengambilan keputusan (decision making), analisis asumsi (analyzing asumption), dan inkuiri sains (scientific inquiry) (Krulik, S. and Rudnik, J. A.,1996). Cara berpikir ini mengembangkan penalaran yang kohesif, logis, dapat dipercaya, ringkas, dan meyakinkan (Ennis, 1985).

Rendahnya keterampilan berpikir kritis siswa dilihat dari cara siswa dalam merumuskan suatu pertanyaan, memberikan argumentasi dan memberikan solusi atas permasalahan ada. Siswa cenderung menyelesaikan masalah dengan mencari jawaban dari buku dan LKS sehingga jika diberikan masalah yang jawabannya tidak tersurat di bahan ajar maka siswa tidak mampu menjawab pertanyaan tersebut sehingga dapat dikatakan keterampilan berpikir kritis siswa masih rendah dalam memecahkan masalah. Namun kondisi pembelajaran selama ini dimana siswa hanya sebagai objek pembelajaran yang menerima informasi dari guru merupakan kendala yang relatif sulit untuk dirubah. Sehingga berbagai pendekatan pembelajaran perlu dilakukan supaya tujuan pembelajaran dapat tercapai.

Sesuai dengan Permendikbud No. 22 Tahun 2016 tentang Standar Proses Pendidikan Dasar dan Menengah menyatakan, kegiatan pembelajaran sepenuhnya diarahkan pada pengembangan ranah pengetahuan, keterampilan, dan sikap secara utuh melalui pendekatan saintifik dan sangat disarankan menggunakan pendekatan pembelajaran yang menghasilkan karya berbasis pemecahan masalah (problem based learning).

Belajar berdasarkan masalah adalah model pembelajaran yang dasar filosofinya konstruktivisme. Pembelajaran berbasis masalah dirancang berdasarkan masalah riil kehidupan yang bersifat illstructured, terbuka, dan mendua (Forgaty, 1997). Menurut Hmelo-Silver \& Barrows (2006) menyatakan bahwa masalah yang dimunculkan dalam pembelajaran PBL tidak memiliki jawaban yang tunggal, artinya para siswa harus terlibat dalam eksplorasi dengan beberapa jalur solusi. Keterlibatan siswa dalam pemecahan masalah inilah yang dapat mengembangkan kemampuan berpikir siswa sebagai langkah memecahkan permasalahan yang dibahas serta dapat mengambil simpulan berdasarkan pemahaman mereka.

Penelitian dan pengembangan yang dilakukan oleh Fariroh (2015), menunjukkan bahwa pengembangan perangkat pembelajaran berbasis $\mathrm{PBL}$ layak digunakan dalam pembelajaran dan perangkat pembelajaran berbasis $\mathrm{PBL}$ efektif meningkatkan keterampialan berpikir kritis siswa. Hal senada dinyatakan oleh Sadia dan Subagia (2008) bahwa bahwa model pembelajaran berbasis masalah dapat meningkatkan prestasi belajar siswa, khsusnya untuk meningatkan keterampilan berpikir kritis siswa.

Berdasarkan masalah tersebut peneliti merasa perlu untuk melakukan penelitian dan pengembangan dengan judul "Pengembangan LKS Sains dengan setting model pembelajaran PBL untuk meningkatkan keterampilan berpikir kritis dan efikasi diri siswa SMP" menurut peneliti layak untuk diangkat sebagai sebuah penelitian.

\section{Metode}

Penelitian ini diarahkan pada pengujian model melalui pengembangan suatu produk perangkat pembelajaran Sains SMP. Metode yang digunakan adalah penelitian dan pengembangan (Research and Development). Produk yang dikembangkan adalah Lembar Kerja Siswa (LKS) Sains SMP dengan seting model pembelajaran PBL untuk kelas VII.

Instrumen yang digunakan dalam penelitian ini yaitu (1) lembar validasi instrumen (2) lembar observasi keterlaksanaan pembelajaran, (3) angket respon guru dan siswa terhadap komponen LKS, dan (4) tes keterampilan berpikir kritis serta kuisioner efikasi diri. Model pengembangan LKS yang digunakan pada penelitian ini adalah model pengembangan yang disarankan oleh Thiagarajan et al. (1974) adalah model 4-D, Model ini terdiri dari 4 tahap pengembangan, yaitu define (Pendifinisian), design (Perencanaan), develop (Pengembangan), dan disseminate (Penyebaran) .

Uji Empiris penelitian ini dilakukan di SMP Negeri 4 Singaraja. Subjek penelitian adalah orang-orang yang terlibat dalam memperoleh perangkat pembelajaran berupa Lembar Kerja Siswa (LKS) yang valid, praktis, dan efektif. Subyek penelitian ini adalah dosen sebagai tim ahli, guru sebagai praktisi dan siswa kelas VII sebagai uji coba lapangan terbatas LKS. Objek penelitian ini adalah produk yang akan dikembangkan yaitu Lembar Kerja Siswa (LKS) sains dengan setting model pembelajaran PBL. 
TSCJ, Vol 1 No 2, Tahun 2018

p-ISSN : 2615-4692 e-ISSN : 2615-6105

Tabel 1. Kriteria Validitas LKS

\begin{tabular}{|c|c|}
\hline Skor & Kategori \\
\hline $3,5 \leq \mathrm{Sr}<4,0$ & Sangat valid (sangat layak) \\
\hline $2,5 \leq \mathrm{Sr}<3,5$ & Valid (layak) \\
\hline $1,5 \leq \mathrm{Sr}<2,5$ & Tidak valid (tidak layak) \\
\hline $1,0 \leq \mathrm{Sr}<1,5$ & $\begin{array}{l}\text { Sangat tidak valid (sangat } \\
\text { tidak layak) }\end{array}$ \\
\hline
\end{tabular}

Tabel 2.Kriteria Kepraktisan LKS

\begin{tabular}{|c|c|}
\hline Skor & Kategori \\
\hline $3,5 \leq \mathrm{Sr}<4,0$ & Sangat praktis \\
\hline $2,5 \leq \mathrm{Sr}<3,5$ & Praktis \\
\hline $1,5 \leq \mathrm{Sr}<2,5$ & Tidak praktis \\
\hline $1,0 \leq \mathrm{Sr}<1,5$ & Sangat tidak praktis \\
\hline
\end{tabular}

Peningkatan keterampilan berpikir kritis dan efikasi diri sebelum dan sesudah pembelajaran dilakuan dengan pertimbangan hasil analisis gain score. Untuk menguji hipotesis penelitian yang berkaitan dengan efektivitas LKS pembelajaran dalam meningkatkan keterampilan berpikir kritis dan efikasi diri siswa digunakan uji-t pihak kanan sampel berpasangan (Paired t test)..

\section{Hasil dan Pembahasan}

Hasil dari penelitian ini berupa produk LKS Sains SMP dengan setting model pembelajaran PBL. Total LKS yang dikembangkan adalah sebaknyak 12 LKS, dengan tema sebagai berikut; 1) komponen ekosistem, 2) pola interaksi makhluk hidup,3) interaksi manusia yang mempengaruhi ekosistem, 4) pencemaran air, 5) pencemaran udara, 6) pencemaran tanah, 7) efek rumah kaca, 8) penyebab dan dampak pemanasan global, 9) lapisan ozon, 10) gempa bumi dan tsunami, 11) gunung merapi, 12) peristiwa banjir.

Uji coba tes keterampilan berpikir kritis dan kuisioner efikasi diri diberikan kepada kelas yang sudah pernah mendapatkan materi pencemaran lingkungan. Berdasarkan hasil analisis validitas tes keterampilan bepikir kritis dan efikasi diri siswa dengan menggunakan rumus teknik korelasi product moment dan uji reliabiltas menggunakan rumus/formula Alpha cronbach, diperoleh instrumen yang layak dipakai pada kegiatan uji coba yaitu tes keterampilan bepikir kritis dan efikasi diri siswa dinyatakan valid karena $r_{\text {hitung }}>r_{\text {tabel }}$ dan reliabelitas sebesar 0,79 dengan kategori tinggi untuk tes keterampilan berpikir kritis dan 0,96 untuk kuisioner efikasi diri siswa dengan kategori reliabelitas sangat tinggi.

\section{Uji Validasi LKS}

LKS sains dengan setting model PBL melewati dua tahap validasi yaitu validasi ahli dan validasi praktisi. Tahap pertama validasi ahli meliputi ahli media dan desain pembelajaran dalam kegiatan Focus Group Discusion (FGD) dan tahap kedua validasi oleh 10 guru sebagai praktisi di sekolah.

Tabel 3. Validasi Ahli Media dan Desain Pembelajaran

\begin{tabular}{lccc}
\hline No & Aspek penilaian & Rata-rata & Kategori \\
\hline 1 & Kebahasaan LKS & 3,4 & Valid \\
2 & Sajian LKS & 3,4 & Valid \\
3 & Kegrafisan & 3,3 & Valid \\
4 & Isi LKS & 3,5 & Valid \\
5 & Desain Antar Muka & 3,0 & Valid \\
6 & Produktivitas dan Inovasi LKS & 3,5 & Valid \\
7 & Tata tulis LKS & 2,6 & Valid \\
& Rata-rata Keseluruhan & $\mathbf{3 , 2}$ & Valid \\
\hline
\end{tabular}


TSCJ, Vol 1 No 2, Tahun 2018

p-ISSN : 2615-4692 e-ISSN : 2615-6105

Tabel 4. Hasil Uji Validasi 10 Orang Guru

\begin{tabular}{llcc}
\hline No & Aspek Penilaian & Rata-rata & Kategori \\
\hline 1. & Isi & 3,5 & Valid \\
2 & Bahasa & 3,4 & Valid \\
3 & Bentuk Fisik & 3,5 & Valid \\
& Rata-rata Total & $\mathbf{3 , 4}$ & Valid \\
\hline
\end{tabular}

Berdasarkan hasil validasi ahli media dan desain pembelajaran serta validasi oleh 10 orang guru pada Tabel 3 dan 4. LKS sains dengan setting PBL berada pada kategori valid artinya layak digunakan sebagai media pembelajaran.

\section{Uji Kepraktisan LKS}

Kepraktisan LKS dapat diketahui dari: 1) keterlaksanaan LKS, 2) respon 3 orang guru dan 3) respon dari 38 siswa setelah menggunakan LKS.

Tabel 5. Rekapitulasi Uji Kepraktisan LKS

\begin{tabular}{lcl}
\multicolumn{1}{c}{ Aspek Penilaian } & Rata-rata & Kategori \\
\hline Keterlaksanaan LKS & 3,4 & Praktis \\
Repon guru & 3,2 & Praktis \\
Respon Siswa & 3,4 & Praktis \\
Rata-rata Total & $\mathbf{3 , 3}$ & Praktis \\
\hline
\end{tabular}

Berdasarkan hasil uji kepraktisan pada Tabel 5. Dapat dilihat bahwa LKS sains dengan setting PBL berada pada kategori praktis artinya LKS mudah dilaksanakan oleh guru dan siswa.

\section{Efektivitas LKS Terhadap Keterampilan Berpikir Kritis dan Self-efficacy}

Keefektifan LKS yang dikembangkan diketahui dari nilai perhitungan nilai gain score dan uji t sampel berpasangan. Hasil uji gain score tes keterampilan berpikir kritis dan efikasi diri ditunjukkan oleh Tabel 6 dan Tabel 7.

Tabel 6. Hasil Gain Score Per Indikator Keterampilan Berpikir Kritis

\begin{tabular}{lccccc}
\hline \multicolumn{1}{c}{ Indikator } & $\mathbf{S}_{\text {pre }}$ & $\mathbf{S}_{\text {post }}$ & $\mathbf{S}_{\mathbf{M I}}$ & $\mathbf{( g )}$ & Kategori \\
\hline Merumuskan Masalah & 6,21 & 8,58 & 12 & 0,41 & sedang \\
Memberikan argumen & 8,92 & 11,37 & 16 & 0,35 & sedang \\
Generalisasi Induksi & 4,71 & 6,45 & 8 & 0,53 & sedang \\
Generalisasi Deduksi & 3,89 & 5,13 & 8 & 0,30 & sedang \\
Evaluasi & 4,42 & 5,66 & 8 & 0,35 & sedang \\
Memberikan keputusan & 6,34 & 7,47 & 12 & 0,20 & rendah \\
\hline
\end{tabular}

Berdasarkan perhitungan gain score ternormalisasi $(\mathrm{g})$ tes keterampilan berpikir kritis yang tersaji pada Tabel 6 terlihat bahwa indikator induki memiliki kategori paling tinggi yaitu 0,53 sedangkan indikator memberikan keputusan yang paling rendah dengan skor gain sebesar 0,20 . Hal ini berarti LKS dengan settting PBL mampu meningkatkan skor rata-rata keterampilan berpikir kritis siswa 
TSCJ, Vol 1 No 2, Tahun 2018

p-ISSN : 2615-4692 e-ISSN : 2615-6105

Tabel 7.Rekapitulasi Gain Score Ternormalisasi Efikasi Diri per Dimensi Efikasi Diri Siswa

\begin{tabular}{ccccccc}
\hline $\begin{array}{c}\text { Dimensi Efikasi } \\
\text { Diri }\end{array}$ & Indikator & $\mathbf{S}_{\text {pre }}$ & $\mathbf{S}_{\text {post }}$ & $\mathbf{S}_{\mathbf{M I}}$ & $\mathbf{( g )}$ & Kategori \\
\hline Tingkat & $\mathbf{1}$ & 15,58 & 19,71 & 25 & 0,44 & Sedang \\
(level) & $\mathbf{2}$ & 68,05 & 86,74 & 105 & 0,51 & Sedang \\
Jumlah & & $\mathbf{8 3 , 6 3}$ & $\mathbf{1 0 6 , 4 5}$ & $\mathbf{1 3 0}$ & $\mathbf{0 , 4 7}$ & Sedang \\
Keluasan & $\mathbf{3}$ & 16,05 & 20,00 & 25 & 0,44 & Sedang \\
(Generality) & $\mathbf{4}$ & 16,39 & 20,97 & 25 & 0,53 & Sedang \\
Jumlah & & $\mathbf{3 2 , 4 4}$ & $\mathbf{4 0 , 9 7}$ & $\mathbf{5 0}$ & $\mathbf{0 , 4 9}$ & Sedang \\
Kekuatan & $\mathbf{5}$ & 15,00 & 20,58 & 25 & 0,56 & Sedang \\
(Strenght) & $\mathbf{6}$ & 15,55 & 20,87 & 25 & 0,56 & Sedang \\
Jumlah & & $\mathbf{3 0 , 5 5}$ & $\mathbf{4 1 , 4 5}$ & $\mathbf{5 0}$ & $\mathbf{0 , 5 6}$ & Sedang \\
Total Skor Rata-rata & $\mathbf{1 4 6 , 6}$ & $\mathbf{1 8 8 , 9}$ & $\mathbf{2 3 0}$ & $\mathbf{0 , 5 0}$ & Sedang \\
\hline
\end{tabular}

Keterangan :

Spost = skor test akhir

Spre = skor tes awal

$\mathrm{SMi}=$ skor maksimal ideal

Indikator :

1. Berwawasan optimis

2. Menyelesaikan tugas

3. Kondisi beragam

4. Pengalaman hidup

5. Meningkatkan upaya

6. Komitmen

Berdasarkan Tabel 7. terlihat bahwa efikasi diri siswa sebelum dan sesudah diukur dengan perhitungan gain score termasuk kategori sedang yaitu 0.50 karena berada pada interval $0,7 \geq(\mathrm{g}) \geq 0,3$. Efikasi diri yang diukur menggunakan acuan Science Self-efiicacy (SSE) dengan tiga dimensi yaitu dimensi level, generality, dan strength. Pada Tabel 7 terlihat bahwa dimensi Stenght menunjukan perubahan efikasi diri paling tinggi dengan gain score 0,56 dengan indikator meningkatkan upaya dan berkomitmen.

Teknik analisis data yang digunakan untuk menguji hipotesis penelitian adalah dengan menggunakan uji-t satu pihak kanan sampel berpasangan.

Berdasarkan pada hasil uji-t dengan bantuan SPSS 16 didapatkan nilai thitung>ttabel atau $13,407>1,687$ dengan taraf signifikansi $(p)<0,05$ sehingga dapat disimpulkan bahwa $\mathrm{Ha}$ diterima dan Ho ditolak. Hal ini berarti keterampilan berpikir kritis siswa setelah pembelajaran menggunakan LKS lebih baik dari pada sebelum menggunakan LKS dengan setting problem based learning. Hal yang sama juga ditunjukan pada uji hipotesis kedua yaitu menunjukan bahwa nilai uji t untuk efikasi diri thitung >ttabel atau 16,838> 1,687 dengan taraf signifikansi $(p)$ $<0.05$ sehingga dapat disimpulkan bahwa Ha diterima dan Ho ditolak. Hal ini berarti keterampilan berpikir kritis dan efikasi diri setelah pembelajaran menggunakan LKS lebih baik dari pada sebelum menggunakan LKS dengan setting problem based learning.

Pembahasan

Validitas LKS diukur dari validitas isi dan validitas konstruk. Validitas isi dapat dilihat dari kesesuaian LKS yang dikembangkan dengan tuntunan kurikulum 2013. LKS yang dikembangkan merepresentasikan seluruh karakteristik model pembelajaran dengan menggunakan sintaks model problem based learning khususnya dari segi materi, aktivitas pembelajaran dan penilaian. Validitas konstruk dapat dilihat dari keterkaitan yang konsisten dari setiap komponen LKS yang dikembangkan dengan karakteristik model pembelajaran yang diterapkan.

Banyak masukan sebagai bahan revisi untuk penyempurnaan LKS seperti konsistensi penempatan ikon gambar, keterbacaan, pengutipan, kesesuaian tujuan dengan indikator, dan pembuatan buku petunjuk guru dalam penggunaan LKS. Hasil penyempurnaan setelah direvisi pada tahap FGD selanjutnya dilakukan uji validasi oleh 10 orang guru yang bagian besar sudah berpengalaman dan menerapkan kurikulum 2013 di sekolah. Tujuan melibatkan guru dalam validasi LKS ini adalah untuk mendapatkan masukan dari segi konten, kesesuaian dengan perkembangan peserta didik, keterbacaan serta tuntutan alokasi waktu di sekolah. LKS 
yang telah divalidasi oleh guru diharapkan mendapatkan masukan kelayakan jika di terapkan di sekolah sebagai media pembelajaran. Terdapat beberapa revisi dalam tahapan ini yang lebih pada kesesuian tingkat kognisi siswa dengan tuntutan kerja dalam LKS yang melatih keterampilan berpikir kritis dan kesesuaian dengan tuntutan kurikulum 2013.

Hasil rekapan skor validasi akhirnya menunjukan LKS yang valid dan layak hal ini disebabkan karena komponen LKS yang dikembangkan rata-rata sesuai dengan indikator yang telah ditetapkan pada instrumen validitas, sehingga layak untuk digunakan dalam pembelajaran.

Ditinjau dari keterlaksanaan LKS dengan materi "pencemaran lingkungan" diperoleh skor rata-rata 3,4 ini berarti LKS yang digunakan dalam pembelajaran praktis dilakukan oleh guru dan siswa. Berdasarkan refleksi dari ketiga pertemuan yang telah dilakukan, maka ada beberapa hal positif yang terjadi selama pembelajaran yaitu:

1) Siswa mulai terbiasa dan percaya diri melakukan kegiatan sesuai dengan yang dituntut dalam LKS. Ini ditandai dengan sikap siswa yang mulai mengerjakan LKS tanpa banyak bertanya tentang apa yang harus dia lakukan.

2) Guru mulai terbiasa memposisikan diri sebagai fasilitator sehingga pembelajaran didominasi oleh siswa.

3) Siswa berperan aktif dengan melakukan berbagai upaya untuk bisa mengikuti aktivitas pembelajaran sesuai tuntutan dalam LKS.

4) Guru dan siswa sudah bisa memanfaatkan waktu belajar dengan baik selama menggunakan LKS.

5) Hasil analisis jawaban siswa yang menuntut keterampilan berpikir kritis mengalami perubahan seperti misalnya kemampuan siswa merumuskan masalah, kemampuan menyusun hipotesis, membuat grafik, dan memberikan argumentasi.

Efektivitas LKS dapat dilihat dari peningkatan skor pretest dan posttest keterampilan berpikir kritis dan efikasi diri siswa. Hasil analisis gain score $(\mathrm{g})$ tes keterampilan berpikir kritis menunjukan perubahan pada kategori sedang hal ini berarti terjadi peningkatan skor rata-rata pretes dan postes pada setiap indikator tes keterampilan berpikir kritis.

Rata-rata hasil pretes keterampilan berpikir kritis masih tergolong rendah karena siswa belum terlatih dalam menghadapi tes yang memuat enam indikator keterampilan berpikir kritis yaitu kemampuan merumuskan masalah, memberikan argumentasi, generalisasi secara induksi, generalisasi secara deduksi, mengevaluasi, dan memberikan keputusan.

Setelah pembelajaran menggunakan LKS dengan setting PBL terlihat kemampuan siswa dalam merumuskan masalah terjadi peningkatan dengan kategori sedang hal ini karena selama mengikuti pembelajaran menggunakan LKS dengan setting PBL siswa dilatih dalam merumuskan pertanyaan setelah membaca permasalahan berupa artikel yang ada di LKS. Rumusan masalah yang tepat akan menuntun siswa untuk mencapai tujuan pembelajaran. Masalah yang telah dirumuskan oleh siswa akan menjadi acuan siswa untuk mencari solusi dengan merancang pemecahan masalah, sehingga siswa saling berdiskusi dengan kelompoknya untuk bisa menjawab pertanyaan yang disusun.

Kemampuan berargumentasi siswa juga meningkat dengan kategori sedang hal ini karena selama mengikuti pembelajaran menggunakan LKS bersetting PBL siswa selalu dituntut untuk menjawab dengan beralasan. Siswa dituntun mealalui pemberian pertanyaan untuk membuka pikirannya dalam memberikan pendapat yang logis diseputaran topik yang sedang dibahas.

Kemampuan siswa dalam menyimpulkan secara induksi menunjukan peningkatan hasil skor gain tertinggi dengan kategori sedang. Hal ini karena siswa dilatih dalam membuat grafik sebagai generalisasi secara induksi berdasarkan data-data yang didapatkan melalui kegiatan pemecahan masalah seperti praktikum. Hasil simpulan berupa grafik membuat siswa lebih mudah dalam membaca hasil pengamatan dan menarik simpulan terkait hipotesis yang telah disusun. Siswa dalam kelompok saling bertukar pikiran untuk memberikan asumsi yang logis dalam penyusunan simpulan yang tepat.

Hasil analisis pada indikator deduksi siswa juga mengalami peningkatan dengan kategori sedang pada uji gain skor. Peningkatan terjadi karena LKS dengan setting PBL menuntun siswa untuk membuat hipotesis setelah siswa membaca artikel atau pernyataan yang menjadi permasalahan pada topik yang akan dibahas. Hipotesis yang disusun menjadi acuan siswa dalam merancang kegiatan pemecahan masalah sesuai dengan tujuan pembelajaran.

Kemampuan evaluasi siswa dalam menjawab tes keterampilan berpikir kritis mengalami peningkatan dengan kategori sedang berdasarakan hasil uji gain skor. Hal ini terjadi karena siswa diberikan latihan soal dalam LKS untuk memperdalam pemahaman siswa khsusnya 
mengevaluasi sesuatu hal yang sudah diterapkan seperti misalnya mengevaluasi program Go green apakah masih efektif atau tidak dalam mengatasi masalah pencemaran lingkungan. Siswa dilatih untuk bisa mengkritisi segala sesuatu yang telah dijalani sebagai bahan evaluasi.

Perubahan skor kemampuan siswa pada indikator memberikan keputusan masih dikategorikan rendah berdasarakan uji gain skor.Rendahnya perubahan nilai pretes dengan postes siswa dikarenakan siswa kurang mampu dalam memberikan tindakan atau solusi untuk memecahkan masalah. Siswa masih belum terbiasa menentukan kemungkinan solusi yang tepat dikarenakan siswa belum mempunyai pengalaman dalam memberikan suatu tindakan terhadap masalah yang dihadapi. misalnya solusi untuk mengatasi dan mencegah peristiwa pencemaran air.

Selanjutnya peningkatan efikasi diri juga terjadi setelah siswa diberikan pembelajaran dengan menggunakan LKS dengan setting PBL. Peningkatan efikasi diri siswa dilihat dari hasil kuisioner yang dianalisis berdasarkan analisis gain skor (g). Hasil analisis efikasi diri siswa secara keseluruhan berada pada kategori sedang ini berarti setelah menggunakan LKS dengan setting PBL siswa memiliki keyakinan lebih tinggi dalam dirinya. Efikasi diri siswa diukur berdasarakan tiga dimensi yaitu dimensi tingkat, keluasan, dan kekuatan. Setiap dimensi memiliki indikator yaitu dimensi tingkat terdiri dari indikator berwawasan optimis dan menyelesaikan tugas, dimensi keluasan terdiri dari indikator menyikapi kondisi beragam, dan pengalaman hidup, dan untuk dimensi kekuatan terdiri dari indikator meningkatkan upaya dan berkomitmen.

Peningkatan efikasi diri siswa terjadi karena setiap aktivitas pembelajaran menggunakan LKS bersetting PBL mampu memberikan kebebasan kepada siswa untuk berani bekerja sesuai dengan tujuan pembelajaran. LKS dengan setting PBL memiliki beberapa fase belajar yang membuat siswa lebih bersemangat dan antusias mengikuti pembelajaran. Pada fase pendahualan siswa diberikan apersepsi dan motivasi berupa sajian gambar dan pertanyaan kemudian siswa diajak untuk saling bertukar pengalaman terkait permasalahan diseputaran topik. Pada fase penyajian masalah siswa diberikan tugas-tugas yang meliputi merumuskan pertanyaan, pengajuan hipotesis, pengumpulan fakta, mensintesa informasi yang tersedia melalui kegiatan inkuiri dan merancang kegiatan penyelidikan yang berkaitan upaya pemecahan masalah. Selanjutnya pada fase tindak lanjut masalah dilakukan penyelidikan dalam upaya melakukan pemecahan masalah. Pada tahap ini siswa harus memiliki tanggung jawab dan keyakinan diri untuk dapat memecahkan permasalahan yang dihadapi.

Pada tahap selanjutnya yaitu fase presentasi, siswa dilatih menjadi presenter yang baik dan belajar berkomunikasi didepan umum. Pada tahap ini, siswa harus memiliki keyakinan atau kepercayaan diri dalam melakukan presentasi guna meyakinkan audien terhadap hasil pemecahan masalahnya. Kegiatan presentasi ini sangat penting dilakukan dalam melatih keyakinan diri siswa, sehingga siswa menjadi terbiasa berbicara atau mengemukakan pendapatnya di depan publik. Selama kegiatan presentasi siswa saling mengkritisi dan memberikan penguatan berupa tepuk tangan sehiingga hal ini membuat siswa merasa lebih yakin akan kemampuan yang dimiliki. Hal ini sejalan dengan Hasil penelitian Hackett (1990) menunjukan bahwa pengalaman sukses menghasilkan peningkatan efikasi diri dan minat pada tugas sedangkan kegagalan tugas menghasilkan penurunan efikasi diri dan minat pada tugas.

Hasil analisis paired- $t$ test dilakukan untuk menguji hipotesis yang disusun. Berdasarakan hasil pengujian menunjukan bahwa LKS dengan setting PBL efektif untuk meningkatkan keterampilan berpikir kritis dan efikasi diri siswa. Hasil penelitian ini sejalan dengan penelitian yang dilakukan oleh Fariroh (2015) menunjukan bahwa pengembangan perangkat pembelajaran berbasis PBL layak digunakan dan efektif untuk meningkatkan keterampilan berpikir kritis.

Keefektifan LKS dalam meningkatkan keterampilan berpikir kritis dan efikasi diri siswa disebabkan oleh beberapa faktor antara lain : 1) Siswa diberikan kebebasan berekspresi untuk mengerjakan LKS, khususnya dalam merancang aktivitas yang akan dilakukannya, 2) Siswa selalu dibimbing oleh guru untuk bisa menyelesaikan LKS dengan tepat waktu untuk mencapai tujuan pembelajaran, 3) siswa dilatih berpikir rasional dalam memecahkan masalah, 4) Siswa dilatih untuk tidak mudah percaya akan informasi yang didapatkan, sehingga siswa perlu pembuktian secara empiris, 5) Siswa mendapatkan kesempatan untuk mengembangkan efikasi diri melalui aktivitas diskusi, presentasi, dan refleksi diri.

4.

an dan Saran

Simpul 
Berdasarkan hasil penelitian, maka dapat diajukan beberapa saran untuk mengembangkan LKS dan meningkatkan keterampilan berpikir kritis dan efikasi diri siswa : (1) LKS mesti ditambahkan beberapa contoh soal yang untuk melatih kemampuan deduksi dan memberikan keputusan sehingga semua indikator keterampilan berpikir kritis siwa dapat ditingkatkan, (2) Untuk membangkitkan efikasi diri siswa, guru mesti memberikan kesempatan kepada semua siswa untuk melakukan presentasi di depan kelas dan berikan penguatan (reward) kepada setiap siswa yang telah berhasil melakukan tugas dengan baik, (3) Untuk mengatasi kekurangan waktu guru bisa memberikan penugasan terhadap LKS yang dirasa memerlukan waktu yang cukup lama sehiingga LKS yang digunakan dapat berjalan dengan baik dan lancar.

\section{Daftar Pustaka}

Bandura,A.1977. Self-efficacy : Toword A Unifying Theory of behavioral change. Psychological review. 84(2) : 191-215

Borrow, H..S.1996. Problem-Based Learning in Medicine and Beyond: A Brief Overview. New Directions for Teaching and learning.Jossey-Bass Publisher.

Chen,Jason.A and Usher,Ellen.L.2013. Profiles of the sources of science self-efficacy.Learning and Individual Differences.24(2013): 11-21.

Carin, A.A. and Sund, R.B. 1993. Teaching Modern Science. Six Edition. New York : Macmillan Publishing Company.

Depdiknas. 2008. Panduan Pengembangan Bahan Ajar. Jakarta: Direktorat Pembinaan SMA, Dirjen Mandikdasmen, Depdiknas.

Ennis, R.H.1985. Goal Critical Thinking Curriculum. Dalam: Costa, A.L.(Ed.): Developing Minds: a resourse book for teacing thinking. Alexandria, Virginia: Association for Supervision and Curriculum Developing (ASCD), 54-57.

Fariroh, A.2015. "Pengembangan Perangkat pembelajaran berbasis Problem Based Learning pada materi virus kelas X SMA". Skripsi. Jurusan Pendidikan Biologi. FMIPA. Univeristas pendidkan semarang.

Hendro Darmodjo dan Jenny R.E. Kaligis. (1992). Pendidikan IPA II. Jakarta : Depdikbud

Hmelo -Silver, C. E., and Barraws, H. S. 2006. Goals and strategi of a problem based learning facilitator. The interdisciplinary Journal of Problem based Learning, 1(1), 21-39.

$\mathrm{K}$ e m e $\mathrm{ndikn}$ a s. 2011 . P a n d u a n Pengembangan Pembelajaran IPA secara Terpadu. Jakarta: Kementrian Pendidikan Nasional Direktorat Jenderal Pendidikan Dasar direktorat Pembinaan Sekolah Menengah Pertama

Krulik, S. and Rudnik, J. A. 1996. The New Source Book Teaching Reasioning and Pbroblem Solving in Junior and Senior Hig School. Massachusets: Allyn \& Bacon

Kaur, Gurpreet. 2013. Scientific attitude in relation to critical thinking among teachers.Educationia Confab.2(8): 24-29.

OECD. 2013. PISA 2012 result : What student know and can do - student performance in mathematics, reading and science (volume i). sumber : https://www.oecd.org/pisa/keyfindings/pisa-2012-results-volume-I.pdf (Diakses pada tanggal 20 Nopember 2016)

Sadia, I W., Subagia, W., Natajaya, I W.2007. Pengembangan model dan perangkat pembelajaran untuk meningkatkan keterampilan berpikir kritis (critical thinking skills) siswa seklah menengah pertama (SMP) dan sekolah menengah atas (SMA). Laporan penelitian . universitas pendidikan ganesha singaraja. 
Sadra, I.W. 2007. "Pengembangan Model Pembelajaran Matematika Berwawasan Lingkungan dalam Pelatihan Guru Kelas Satu Sekolah Dasar". Disertasi (Tidak dipublikasikan) Surabaya: Unesa

Thiagarajan, S., Semmel, D.S.and Semmel, M.L.(1974). Instructional Development for Training Teacher Of Exceptional Children A SaurceMinneseta : Indiana University.. 